\title{
Expression and Localization of Endothelin Receptors: Implications for the Involvement of Peripheral Glia in Nociception
}

\author{
James D. Pomonis, Scott D. Rogers, Christopher M. Peters, Joseph R. Ghilardi, and Patrick W. Mantyh \\ Departments of Preventive Science, Neuroscience, and Psychiatry, University of Minnesota, Minneapolis, Minnesota \\ 55455, and Veterans Affairs Medical Center, Minneapolis, Minnesota 55417
}

The endothelins (ETs) are peptides that have a diverse array of functions mediated by two receptor subtypes, the endothelin $A$ receptor $\left(E T_{A} R\right)$ and the endothelin $B$ receptor $\left(E T_{B} R\right)$. Pharmacological studies have suggested that in peripheral tissues, $\mathrm{ET}_{\mathrm{A}} \mathrm{R}$ expression may play a role in signaling acute or neuropathic pain, whereas $E T_{B} R$ expression may be involved in the transmission of chronic inflammatory pain. To begin to define the mechanisms by which ET can drive nociceptive signaling, autoradiography and immunohistochemistry were used to examine the distribution of $E T_{A} R$ and $E T_{B} R$ in dorsal root ganglia (DRG) and peripheral nerve of the rat, rabbit, and monkey. In DRG and peripheral nerve, $\mathrm{ET}_{\mathrm{A}} \mathrm{R}$-immunoreactivity was present in a subset of small-sized peptidergic and nonpeptidergic sen- sory neurons and their axons and to a lesser extent in a subset of medium-sized sensory neurons. However, $\mathrm{ET}_{\mathrm{B}} \mathrm{R}$-immunoreactivity was not seen in DRG neurons or axons but rather in DRG satellite cells and nonmyelinating ensheathing Schwann cells. Thus, when ETs are released in peripheral tissues, they could act directly on $E T_{A} R$-expressing sensory neurons and on $E_{B} R$-expressing DRG satellite cells or nonmyelinating Schwann cells. These data indicate that ETs can have direct, nociceptive effects on the peripheral sensory nervous system and that peripheral glia may be directly involved in signaling nociceptive events in peripheral tissues.

Key words: ensheathing Schwann cells; satellite cells; inflammatory pain; cancer pain; sensory neurons; endothelin
The endothelins (ETs) are 21 amino acid peptides originally cloned from bovine aortic endothelial cells (Yanagisawa et al., 1988) and are expressed as three biologically active peptides: ET-1, ET-2, and ET-3. Endothelins are expressed by a variety of cell types including endothelial cells (Yanagisawa et al., 1988), macrophages (Ehrenreich et al., 1990), astrocytes (MacCumber et al., 1990), and neurons (Giaid et al., 1989).

In mammals, ETs produce their biological effects via activation of two receptor subtypes, the endothelin $A$ receptor $\left(E T_{A} R\right)$ and the endothelin $\mathrm{B}$ receptor $\left(\mathrm{ET}_{\mathrm{B}} \mathrm{R}\right)$. ET-1 and ET-2 have greater affinity for $\mathrm{ET}_{\mathrm{A}} \mathrm{R}$ than does $\mathrm{ET}-3$, whereas all three peptides have similar affinities for $E_{B} R$. $E_{A} R$ and $E_{B} R$ are coupled to multiple but distinct second messenger systems. Activation of $\mathrm{ET}_{\mathrm{A}} \mathrm{R}$ stimulates cAMP formation, whereas activation of $\mathrm{ET}_{\mathrm{B}} \mathrm{R}$ inhibits cAMP formation while increasing phosphoinositide turnover, mitogen-activated protein kinase activation, and intracellular calcium levels (MacCumber et al., 1990; Aramori and Nakanishi, 1992; Kasuya et al., 1994; Kitamura et al., 1999). These receptors also have different intracellular trafficking pathways because ligand stimulation of $\mathrm{ET}_{\mathrm{A}} \mathrm{R}$ induces internalization and recycling of $E T_{A} R$, whereas $E T_{B} R$ internalizes but apparently does not recycle to the plasma membrane (Bremnes et al., 2000). $\mathrm{ET}_{\mathrm{A}} \mathrm{R}$ and $\mathrm{ET}_{\mathrm{B}} \mathrm{R}$ are widely distributed throughout the body, but each receptor has a unique distribution. $\mathrm{ET}_{\mathrm{A}} \mathrm{R}$ mRNA is abun-

\footnotetext{
Received Sept. 22, 2000; revised Oct. 31, 2000; accepted Nov. 3, 2000.

This work was supported by National Institute of Neurological Diseases and Stroke Grant NS 23970, by the National Institute on Drug Abuse Grant DA 11986, by National Institute of Dental and Craniofacial Research Grant DE 07288, by a Veterans Administration Merit Review, and by the Spinal Cord Society. We thank Drs. Gudarz Davar and Prisca Honore for helpf ul comments.

Correspondence should be addressed to Dr. Patrick W. Mantyh, Neurosystems Center, 18-208 Moos Tower, 515 Delaware Street Southeast, Minneapolis, MN 55455. E-mail: manty001@tc.umn.edu.

Copyright (c) 2001 Society for Neuroscience 0270-6474/01/210999-08\$15.00/0
}

dant in vascular smooth muscle cells in a variety of tissues, whereas $\mathrm{ET}_{\mathrm{B}} \mathrm{R}$ mRNA is present in a wider variety of cell types with predominant expression in vascular endothelial and glial cells in the brain (Hori et al., 1992).

Several biological processes are mediated by ET with the most studied being its potent vasoconstrictive activity, but ETs also display pulmonary (de Nucci et al., 1988), renal (Harris et al., 1991), and neural effects (MacCumber et al., 1990; Baba, 1998). Previous studies also suggest that ETs may play a role in the transmission of nociceptive information in both animals and humans (Yoshizawa et al., 1989; Dahlof et al., 1990; Raffa et al., 1991, 1996a,b; Davar et al., 1998; Fareed et al., 2000; Piovezan et al., 2000). However, because of the robust vasoconstrictive activity of ETs, it is unclear whether the generally pronociceptive actions of ETs are caused by direct actions on sensory neurons or whether the effects are mediated indirectly via vasoconstrictioninduced ischemia and subsequent acidosis.

To begin to understand the mechanisms by which peripherally released ETs can generate nociceptive behaviors, receptor autoradiography and immunohistochemistry with confocal microscopy were used to define the cell types that express these receptors in sensory ganglia and peripheral nerve of the rat, rabbit, and monkey. The results suggest that two distinct mechanisms may be involved in ET-mediated nociception, one by ETs interacting with $\mathrm{ET}_{\mathrm{A}} \mathrm{R}$-expressing neurons and the other by ETs acting at $\mathrm{ET}_{\mathrm{B}} \mathrm{R}$ expressed by dorsal root ganglion (DRG) satellite cells and ensheathing Schwann cells (ESCs). Elucidating the mechanisms by which ETs activate DRG satellite cells and ESCs to induce a nociceptive response may provide insight into the role that peripheral glia play in nociceptive signaling.

\section{MATERIALS AND METHODS}

Animals and tissue preparation. All procedures were approved by the University of Minnesota Institutional Animal Care and Use Committee 
and by the Subcommittee on Animal Studies at the Minneapolis Veterans Affairs Hospital. A total of 20 male Sprague Dawley rats (Harlan, Madison, WI), 6 male New Zealand rabbits (Birchwood Valley Farms, Red Wing, MN), and 2 male rhesus monkeys were used in the current studies. All animals were normal, naive animals with the exception of three rats that, while under ketamine and xylazine anesthesia, had two tight ligatures tied around the sciatic nerve $\sim 1 \mathrm{~cm}$ apart. The animals that received nerve ligations were killed $7 \mathrm{~d}$ after surgery. All animals were deeply anesthetized with sodium pentobarbital and then transcardially perfused with $0.1 \mathrm{M}$ PBS. After perfusion, sciatic nerves and lumbar DRG were collected and placed in Tissue-Tek embedding medium (Miles, Elkhart, IN) and rapidly frozen on dry ice. DRG from the first to fifth lumbar segments (L1-L5) were collected because they represent the major source of sensory nerve fibers in the sciatic nerve. Frozen $15 \mu \mathrm{m}$ sections were cut on a cryostat and thaw mounted onto gelatin-coated slides. Sections were stored at $-70^{\circ} \mathrm{C}$ until used for immunohistochemistry or autoradiography. For autoradiography, DRG sections from rat, rabbit, and monkey were used; for immunohistochemistry, DRG sections were used from rat and rabbit, and sciatic nerve sections from rat were used.

Endothelin receptor binding. Endothelin receptor binding was performed as described previously (Ghilardi et al., 1994; Rogers et al., 1997). Briefly, slide-mounted sections were rinsed in a solution containing 170 mM Tris- $\mathrm{HCl}, 10 \mathrm{~mm} \mathrm{MgCl}_{2}$, and $0.01 \%$ ascorbic acid, $\mathrm{pH}$ 7.4. The tissue sections were subsequently incubated in the same buffer containing $80 \mathrm{pm}$ ${ }^{125}$ I-ET-1 (DuPont NEN, Boston, MA). To determine nonspecific binding, paired serial sections were incubated as described above with the exception that $1 \mu \mathrm{M}$ ET-1 (American Peptide Company, Sunnyvale, CA) was added to the incubation medium. After incubation, the slides were washed twice in $170 \mathrm{~mm}$ Tris- $\mathrm{HCl}$ and then rinsed in distilled water, dried under a stream of cool air, and stored overnight under desiccating conditions. Slides were then processed for emulsion-dipped autoradiography as described previously (Mantyh et al., 1989, 1995). For Nissl counterstaining, slides were immersed in $1 \%$ cresyl fast violet for $30 \mathrm{~min}$, rinsed in distilled water and then in $96 \%$ ethanol, cleared in xylene, and coverslipped. Dark-field and bright-field photomicrographs were taken of the emulsion-dipped and Nissl-counterstained sections. Controls for chemographic artifacts were generated by performing the binding exactly as described except that the radioligand was omitted from the incubation medium. For comparison of ${ }^{125}$ I-ET-1-binding sites and glial fibrillary acidic protein (GFAP)-immunoreactivity, serial sections were alternately processed for ET-1 binding or GFAP-immunoreactivity as described below.

Immunohistochemistry. Slide-mounted sections were rinsed for $10 \mathrm{~min}$ in PBS and then fixed in acetone at $4^{\circ} \mathrm{C}$ for $20 \mathrm{~min}$. Sections were air dried, rehydrated in PBS for $10 \mathrm{~min}$, and then incubated in blocking solution ( $2 \%$ normal donkey serum and $0.3 \%$ Triton X-100 in PBS) for 30 min. The blocking solution was removed, and sections were incubated in the relevant primary antibody. A subset of primary afferent fibers was identified by the use of antibodies against calcitonin gene related peptide (CGRP; rabbit anti-CGRP; 1:8000; Sigma, St. Louis, MO) or against phosphorylated $200 \mathrm{kDa}$ neurofilament protein (rabbit anti-RT-97; 1:500; Serotec, Raleigh, NC), a marker of myelinated neurons and their fibers. Peripheral supporting cells (ESCs and DRG supporting cells) were identified by the use of antibodies against GFAP (mouse anti-GFAP; 1:500; Sigma). Although GFAP is typically considered a marker of astrocytes, it has been shown that ESCs, but not myelinating Schwann cells (MSCs), express GFAP (Jessen and Mirsky, 1984, 1985; Jessen et al., 1984, 1990). Endothelin receptors were identified by the use of sheep anti-ET ${ }_{\mathrm{A}} \mathrm{R}$ (1:200; Research Diagnostics, Inc., Flanders, NJ) and sheep anti-ET $\mathrm{B}_{\mathrm{B}} \mathrm{R}$ (1:200; Research Diagnostics, Inc.). Neuronal nuclei were stained by using mouse anti-NeuN (1:70; Chemicon, Temecula, CA). Tissue sections were incubated in the above antisera overnight at room temperature. For double labeling, after incubation in primary antisera, slides were rinsed three times for $10 \mathrm{~min}$ each in PBS and then incubated overnight at room temperature in a different primary antiserum. After this second incubation, slides were rinsed three times for 10 min each and then incubated in a mixture of biotin-conjugated anti-sheep IgG (1:500; Jackson ImmunoResearch, West Grove, PA; for $\mathrm{ET}_{\mathrm{A}} \mathrm{R}$ and $\mathrm{ET}_{\mathrm{B}} \mathrm{R}$ ) and indocarbocyanine-conjugated antisera (1:600; Jackson ImmunoResearch) raised against either mouse IgG (for GFAP or NeuN) or rabbit IgG (for CGRP or RT-97) for $2 \mathrm{hr}$ at room temperature. Slides were rinsed three times for 10 min each in PBS and then incubated with FITC-conjugated streptavidin (1:500; Jackson ImmunoResearch) for 45

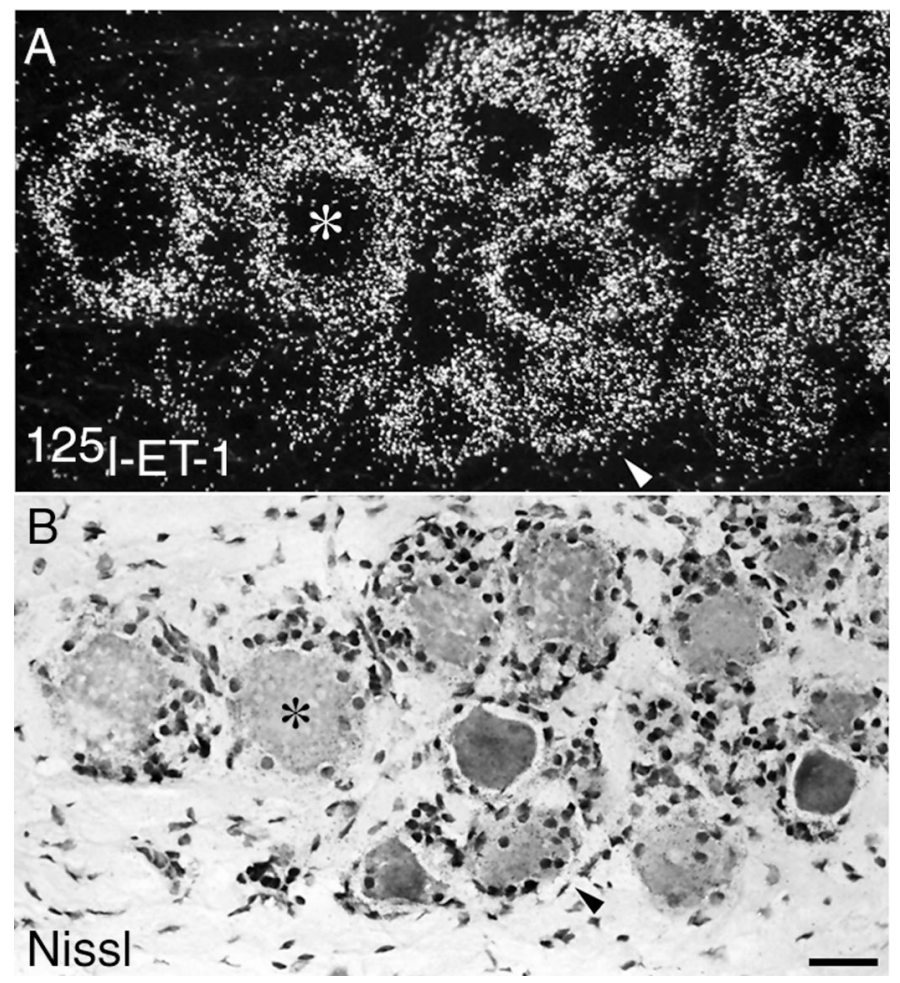

Figure 1. $\quad{ }^{125}$ I-ET-1-binding sites $(A)$ in monkey DRG are most dense in ring-like structures that surround Nissl-stained DRG neuronal cell bodies $(B)$ identified by asterisks, indicating that endothelin receptors are present on DRG satellite cells. However, ${ }^{125}$ I-ET-1-binding sites are also seen over Nissl-stained small-diameter DRG neuronal cell bodies (denoted by arrowheads), indicating that a subpopulation of neurons express endothelin receptors. Scale bar, $50 \mu \mathrm{m}$.

min at room temperature. Sections were then rinsed three times for 10 min each in PBS and coverslipped.

Fluorescent images were acquired by use of an Olympus Fluoview confocal system and an Olympus BX-50 microscope. To determine colocalization of the proteins of interest, color images (red and green) were overlaid so that areas of colocalization appeared yellow. To determine the number of DRG neurons, the following procedure was followed: neuronal cell bodies were counted only if the nucleolus was visible (seen as an area devoid of immunoreactivity in the center of a DRG neuronal cell body), and the size of the cell body was then estimated in square micrometers by use of an eyepiece grid. DRG cell bodies with areas of $<1200 \mu \mathrm{m}^{2}$ were classified as small-diameter neurons, and those with areas $\geq 1200 \mu \mathrm{m}^{2}$ were classified as medium-to-large-diameter neurons. This provides a more accurate description of the distribution of the proteins in cell populations of different sizes. Because of species crossreactivity issues, not all antibodies could be used in all animals. In rabbit, DRG were processed for $\mathrm{ET}_{\mathrm{A}} \mathrm{R}-, \mathrm{ET}_{\mathrm{B}} \mathrm{R}$-, and GFAP-immunoreactivity. In rat DRG and sciatic nerve, all antibodies listed above were used.

\section{RESULTS}

\section{Endothelin receptor distribution in dorsal root ganglia}

Autoradiography for endothelin receptor-binding sites in rat, rabbit, and monkey DRG revealed distinct, dense areas of ${ }^{125} \mathrm{I}$ ET-1 binding, forming ring-like structures within the DRG. This observation is in agreement with a previous report of ${ }^{125}$ I-ET-1binding sites in the rat DRG (Kar et al., 1991). These ring-like structures appeared to correspond to DRG supporting cells because the binding sites closely overlapped with GFAPimmunoreactivity (data not shown) but surrounded, rather than overlapped, Nissl-stained cell bodies in the DRG (Fig. 1). Although ${ }^{125}$ I-ET-1-binding sites in the DRG typically formed these ring-like structures, other, less dense areas of binding were also 

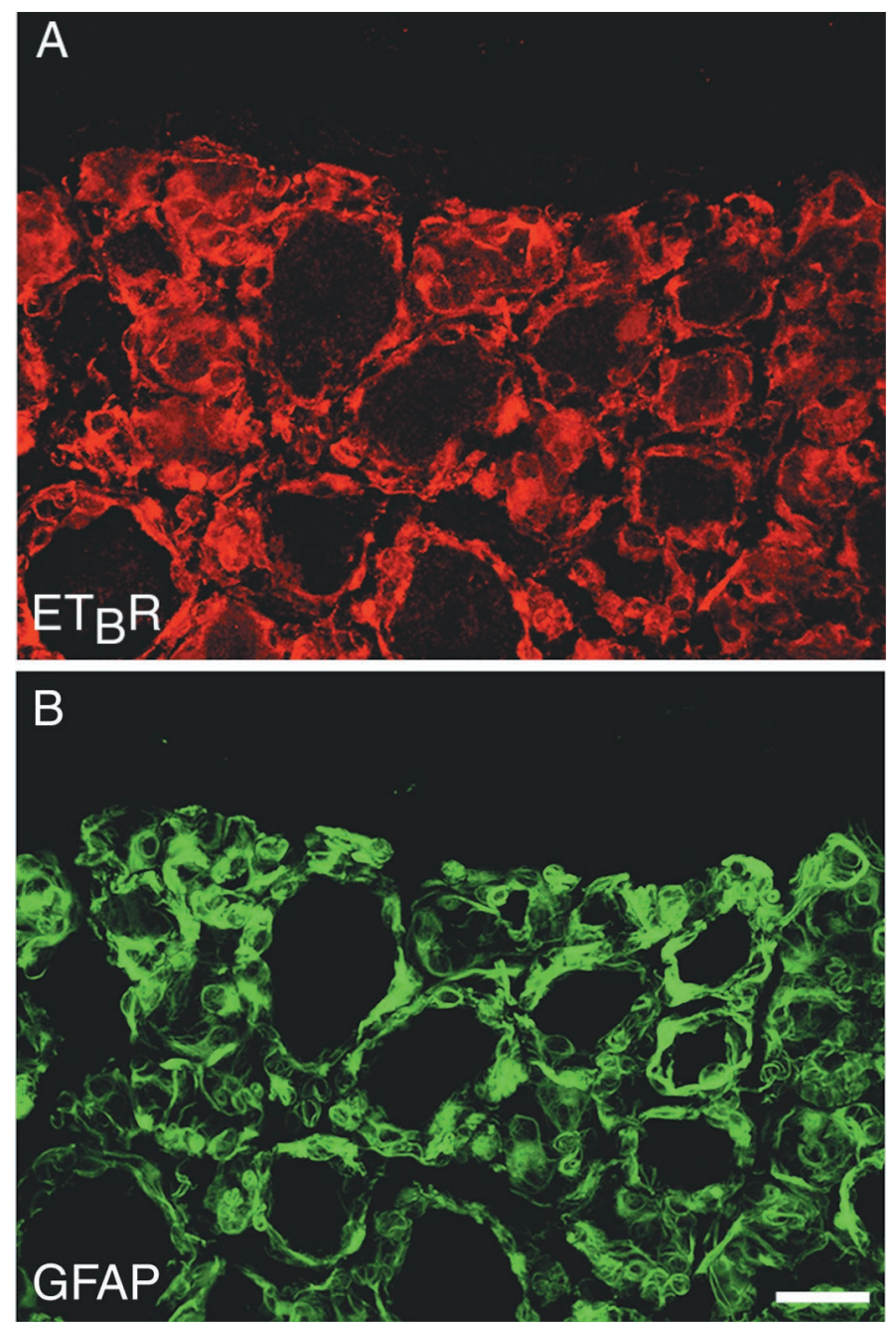

Figure 2. DRG satellite cells express $\mathrm{ET}_{\mathrm{B}} \mathrm{R}$. A single section of rabbit DRG was double labeled for $\mathrm{ET}_{\mathrm{B}} \mathrm{R}$ (shown in red; $A$ ) and for GFAP (shown in green; $B$ ). In DRG, the vast majority of $\mathrm{ET}_{\mathrm{B}} \mathrm{R}$ immunoreactivity colocalized with GFAP-immunoreactivity but was absent from DRG neuronal cell bodies, indicating that $\mathrm{ET}_{\mathrm{B}} \mathrm{R}$ is expressed primarily by peripheral DRG satellite cells. Images are single confocal optical sections. Scale bar, $50 \mu \mathrm{m}$.

distributed over areas corresponding to small-to-mediumdiameter DRG neuronal cell bodies (see Fig. 1, arrowheads). This distribution of ET-1-binding sites was qualitatively similar in all rat, rabbit, and monkey DRG sections examined.

To define at the single-cell level the specific cell types that express $\mathrm{ET}_{\mathrm{A}} \mathrm{R}$ and $\mathrm{ET}_{\mathrm{B}} \mathrm{R}$ in $\mathrm{DRG}$ and peripheral nerve, we used immunohistochemistry and confocal microscopy. These allow for unequivocal single-cell resolution while simultaneously visualizing multiple markers of specific cell types. Double labeling for $\mathrm{ET}_{\mathrm{A}} \mathrm{R}$ or $\mathrm{ET}_{\mathrm{B}} \mathrm{R}$ and markers of peripheral supporting cells or primary afferent fibers revealed a distinctly different distribution of the two receptor subtypes. In rat and rabbit $\mathrm{DRG}, \mathrm{ET}_{\mathrm{B}} \mathrm{R}$ immunoreactivity showed a near one-to-one correspondence with GFAP-immunoreactivity (Fig. 2), indicating that $\mathrm{ET}_{\mathrm{B}} \mathrm{R}$ in $\mathrm{DRG}$ is expressed primarily by DRG satellite cells.

In contrast to the results seen with $\mathrm{ET}_{\mathrm{B}} \mathrm{R}$-immunoreactivity, immunohistochemistry for $\mathrm{ET}_{\mathrm{A}} \mathrm{R}$ in rat and rabbit DRG demonstrated that this receptor is expressed by a subpopulation of primary afferent sensory neurons. $\mathrm{ET}_{\mathrm{A}} \mathrm{R}$-immunoreactivity was seen in a subpopulation of DRG neurons. In the DRG sections examined, $37.5 \pm 3.7$ (mean $\pm \mathrm{SEM}$ ) of the total number of neurons expressed $\mathrm{ET}_{\mathrm{A}} \mathrm{R}$. DRG neurons that express $\mathrm{ET}_{\mathrm{A}} \mathrm{R}$ were primarily small-diameter neurons, with $76.4 \pm 2.8 \%$ of the $\mathrm{ET}_{\mathrm{A}} \mathrm{R}$-ir neurons classified as small-diameter DRG neurons $\left(<1200 \mu \mathrm{m}^{2}\right)$, whereas $23.6 \pm 2.8 \%$ of $\mathrm{ET}_{\mathrm{A}} \mathrm{R}$-ir neurons were classified as medium-to-large-diameter DRG neurons $(\geq 1200$ $\mu \mathrm{m}^{2}$ ). DRG neurons were classified as either small-diameter or medium-to-large-diameter neurons, and importantly, $\mathrm{ET}_{\mathrm{A}} \mathrm{R}$-ir was never observed in large-diameter neurons (i.e., $>1600 \mu \mathrm{m}^{2}$ ). Thus, $\mathrm{ET}_{\mathrm{A}} \mathrm{R}$-ir neurons that were classified as medium-to-largediameter neurons can more specifically be said to be mediumdiameter neurons (typically from 1200 to $1600 \mu \mathrm{m}^{2}$ ).

To define further the population of primary afferent neurons expressing $E T_{A} R$, we stained individual DRG sections for $E_{A} R$ and either CGRP (to denote C fibers; Fig. 3D-F) or RT-97 (to denote A fibers; Fig. 3G-I). We could not determine whether $\mathrm{ET}_{\mathrm{A}} \mathrm{R}$ was expressed by the population of small sensory neurons that bind Bandeira simplicifolia isolectin B4 (IB4) because of technical limitations inherent to the use of the $\mathrm{ET}_{\mathrm{A}} \mathrm{R}$ antiserum and the IB4-labeling process. First, the $\mathrm{ET}_{\mathrm{A}} \mathrm{R}$ antiserum used in the present study will not label formalin-fixed tissue, which is required for IB4 labeling. Second, the procedures for IB4 labeling and $\mathrm{ET}_{\mathrm{A}} \mathrm{R}$ immunohistochemistry each require biotin amplification, rendering the two procedures incompatible. There was a significant amount of colocalization of $\mathrm{ET}_{\mathrm{A}} \mathrm{R}$ and CGRP in DRG neurons but significantly less colocalization of $\mathrm{ET}_{\mathrm{A}} \mathrm{R}$ and RT-97. Of the total number of ETAR-ir neurons counted, $65.9 \pm 6.1 \%$ were immunoreactive for CGRP, whereas $24.0 \pm 3.7 \%$ of ETAR-ir neurons were immunoreactive for RT-97.

\section{Endothelin receptor distribution in sciatic nerve}

Endothelin receptor autoradiography for binding sites in the rat and rabbit sciatic nerve showed a large number of binding sites distributed along the nerve with dense areas of binding forming intermittent bands through the length of the nerve. This pattern of binding was indicative of binding sites present on neuronal fibers, MSCs, or ESCs. Comparison of serial sections alternately processed for ${ }^{125}$ I-ET-1-binding sites and GFAP-immunoreactivity revealed that the areas of dense ${ }^{125}$ I-ET-1 binding closely corresponded with GFAP-immunoreactivity (Fig. 4A,B). However, other less dense binding sites that did not have any apparent relation to GFAP-immunoreactivity were also seen throughout the nerve. These data indicate that the majority of ${ }^{125}$ I-ET-1-binding sites in the sciatic nerve represent endothelin receptors expressed by ESCs but that other ET receptors also are present either on neurons or on MSCs.

Placement of two tight ligatures around the sciatic nerve of rats markedly altered the pattern of ${ }^{125}$ I-ET-1 binding. After this procedure, receptors being transported in sensory neurons usually accumulate between the DRG and the proximal ligature as well as on the far side of the distal ligature. Conversely, receptors that are expressed by peripheral supporting cells accumulate between the two ligatures (Kumara-Siri and Gould, 1980). Seven days after the double ligation, there was a significant buildup of ${ }^{125}$ I-ET-1-binding sites between the two ligatures, with a smaller amount of buildup between the DRG and the proximal ligature (Fig. $4 C$ ). These data are consistent with the expression of ETR by both neurons and peripheral supporting cells.

Virtually all $\mathrm{ET}_{\mathrm{B}} \mathrm{R}$-immunoreactivity in the sciatic nerve colocalized with GFAP-immunoreactivity (Fig. 5A-C), again indicating that $\mathrm{ET}_{\mathrm{B}} \mathrm{R}$ is expressed by ESCs. Conversely, $\mathrm{ET}_{\mathrm{B}} \mathrm{R}$-immuno- 

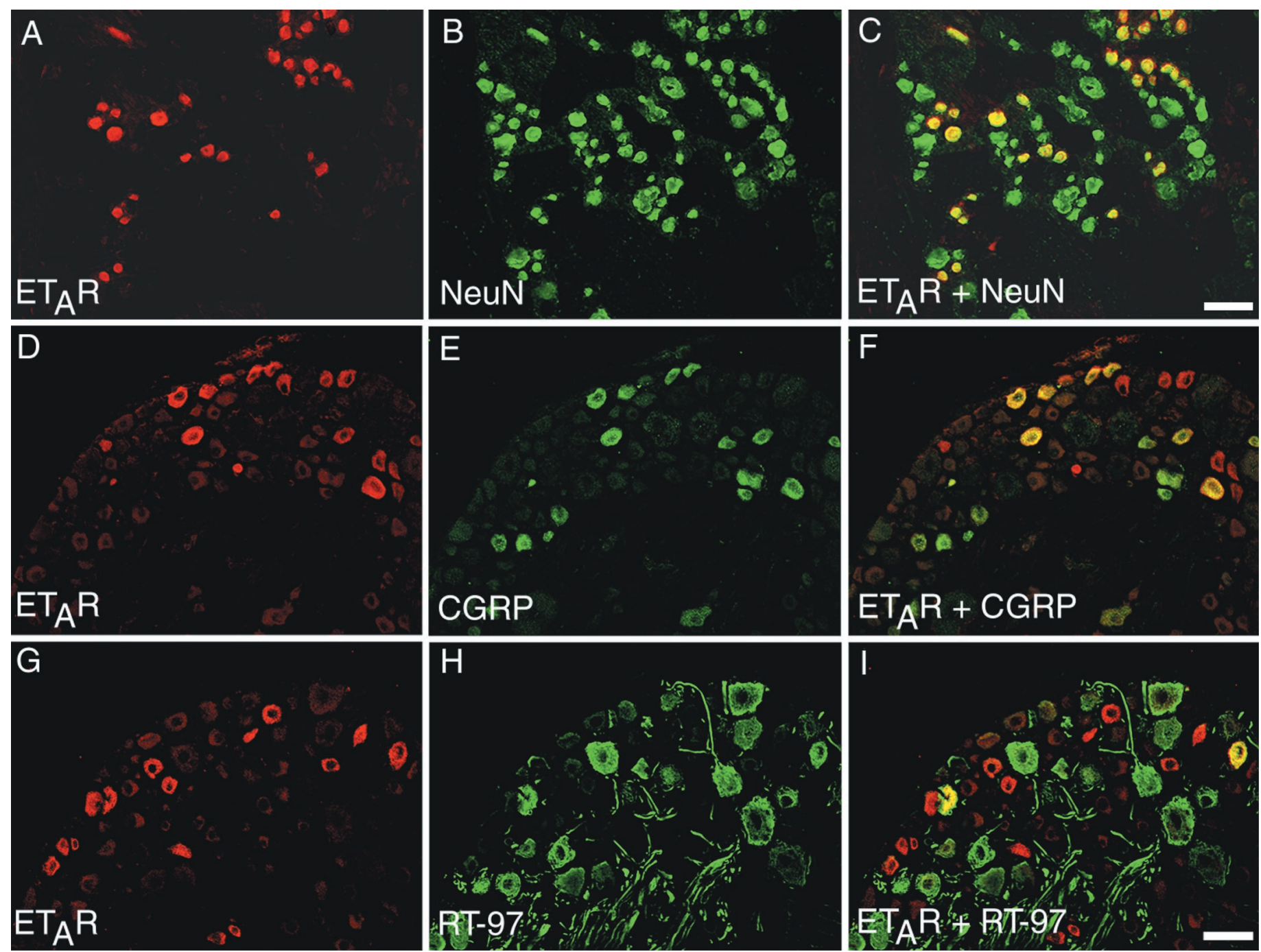

Figure 3. $\mathrm{ET}_{\mathrm{A}} \mathrm{R}$ is expressed primarily by small-diameter neurons of the rat DRG. $A-C$, Single sections through rat DRG were double labeled for ET $\mathrm{A}_{\mathrm{A}}$ $(\mathrm{red} ; A)$ and NeuN, a marker of all neuronal cell bodies ( green; $B)$, to reveal colocalization of the two markers $($ yellow; $C)$. $D-F$, A single section through rat DRG double labeled for $\mathrm{ET}_{\mathrm{A}} \mathrm{R}(\mathrm{red} ; D)$ and CGRP, a marker of unmyelinated primary afferent neurons $($ green; $E)$, to reveal colocalization indicated that approximately half of DRG neurons that were immunoreactive for $\mathrm{ET}_{\mathrm{A}} \mathrm{R}$ were also immunoreactive for CGRP $($ yellow; $F)$. $G-I$, Conversely, when single sections were double labeled for $\mathrm{ET}_{\mathrm{A}} \mathrm{R}($ red $; G)$ and RT-97, a marker of myelinated primary afferent neurons ( green; $H$ ), the incidence of colocalization was much lower $(I)$. Scale bars: $A-C, 50 \mu \mathrm{m} ; D-I, 75 \mu \mathrm{m}$.

reactivity was absent in CGRP-immunoreactive fibers (data not shown). Immunohistochemistry for $\mathrm{ET}_{\mathrm{A}} \mathrm{R}$ in the sciatic nerve also showed a neuronal localization of this receptor. $\mathrm{ET}_{\mathrm{A}} \mathrm{R}$ immunoreactivity showed a high degree of colocalization with CGRP-immunoreactive fibers (Fig. $5 D-F$ ) but showed virtually no colocalization with GFAP-immunoreactive supporting cells (data not shown).

\section{DISCUSSION}

\section{Differences between $E T_{A} R$ and $E T_{B} R$ in the peripheral nervous system}

Different types of pain (e.g., inflammatory pain, neuropathic pain, and bone cancer pain) each generate unique "neurochemical signatures" that are characterized by a unique set of changes in expression of neurochemical markers such as substance P (SP), CGRP, cFos, and GFAP. Thus, different mechanisms may be involved in the generation and maintenance of these different persistent pain states (Hokfelt et al., 1994; Basbaum, 1999; Honore et al., 2000a). The PNS is known to use a variety of neurotransmitters and neuromodulators to convey nociceptive information; ETs are among those entities implicated in this process. The demonstration that $\mathrm{ET}_{\mathrm{A}} \mathrm{R}$ and $\mathrm{ET}_{\mathrm{B}} \mathrm{R}$ are expressed by different cell types in peripheral nerve and sensory ganglia indicates that both may be involved in pain transmission. Expression of $\mathrm{ET}_{\mathrm{A}} \mathrm{R}$ by primary afferent nociceptors provides a mechanism by which peripherally released ET can act directly on sensory neurons, whereas expression of $\mathrm{ET}_{\mathrm{B}} \mathrm{R}$ by ESCs and DRG satellite cells indicates that peripheral glia may play a role in nociceptive signaling.

Peripherally released ET- 1 appears to act at $\mathrm{ET}_{\mathrm{A}} \mathrm{R}$ to generate acute or neuropathic pain because peripheral administration of ET-1 induces nocifensive behaviors that are reversible by administration of $\mathrm{ET}_{\mathrm{A}} \mathrm{R}$-selective antagonists (Dahlof et al., 1990; Raffa et al., 1991, 1996a,b; Davar et al., 1998; Fareed et al., 2000; Jarvis et al., 2000). Still, the mechanism by which $\mathrm{ET}_{\mathrm{A}} \mathrm{R}$ mediates nociception is unclear. Endothelins are potent vasoconstrictors, an effect occurring primarily via $\mathrm{ET}_{\mathrm{A}} \mathrm{R}$ present on vascular smooth muscle cells, including those surrounding neural mi- 

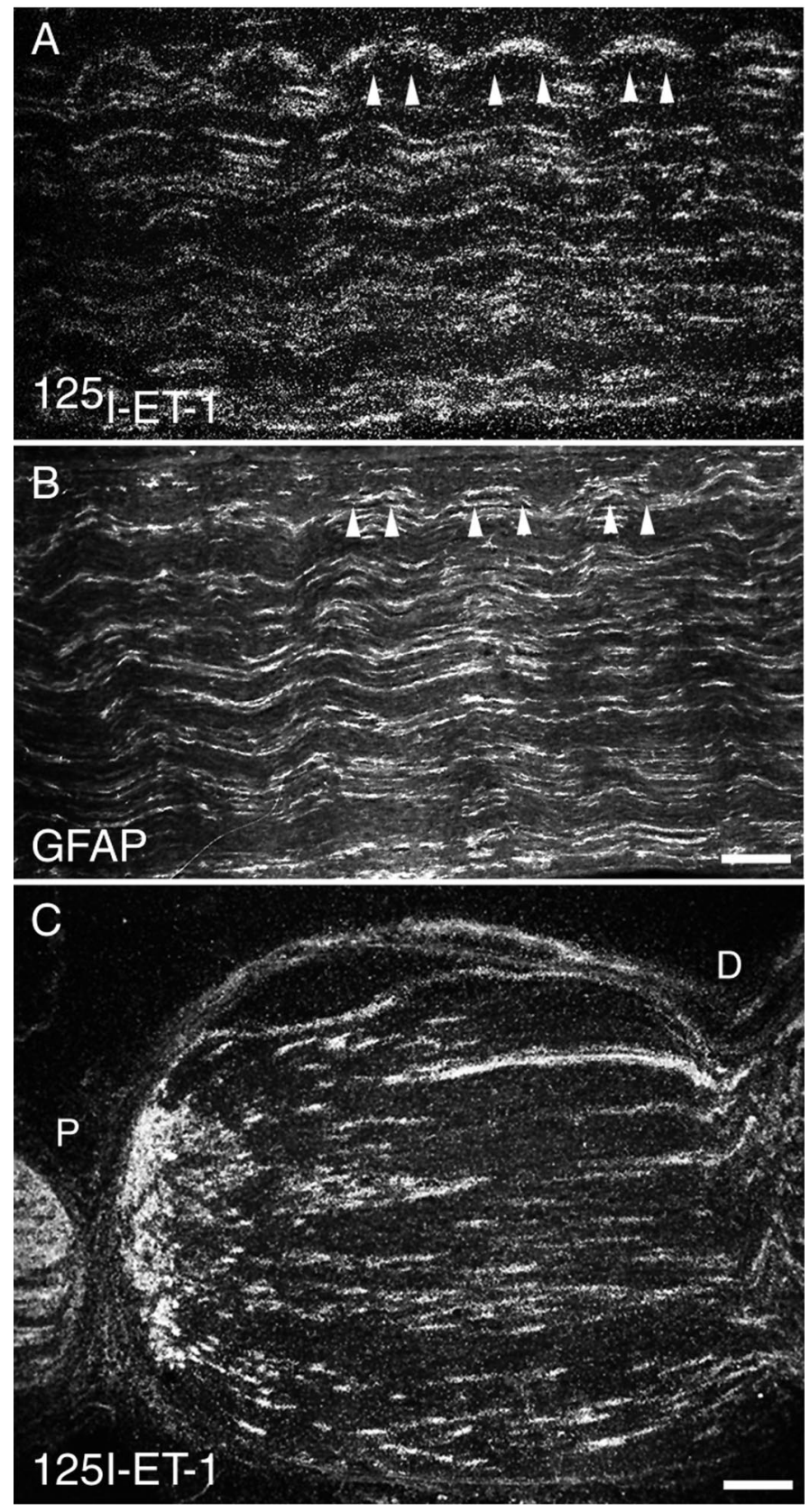

Figure 4. ${ }^{125}$ I-Endothelin-1-binding sites in sciatic nerve indicate that endothelin receptors are expressed by ensheathing Schwann cells. ${ }^{125} \mathrm{I}$ Endothelin-1-binding sites show a close correspondence with GFAPimmunoreactivity. $A, B$, Serial sections processed for ${ }^{125}$ I-ET-1 binding $(A)$ or for GFAP-immunoreactivity $(B)$ suggest that the vast majority of endothelin receptors are located on peripheral supporting cells such as ensheathing (nonmyelinating) Schwann cells. Arrowheads indicate areas of overlap between ${ }^{125} \mathrm{I}$-ET-1-binding sites and GFAP-immunoreactivity. $C$, As further evidence that ${ }^{125}$ I-ET-1-binding sites are present on peripheral supporting cells, ${ }^{125}$ I-ET-1-binding sites accumulate on all sides of two tight ligatures placed $\sim 1 \mathrm{~cm}$ apart in rat sciatic nerve. The accumulation of binding sites that was seen between the two ligatures indicates that a significant number of these binding sites originate in peripheral supporting cells. $P$ indicates the aspect of the nerve proximal to the dorsal root ganglion; $D$ indicates the distal aspect. Scale bars: $A, B, 100 \mu \mathrm{m} ; C, 200 \mu \mathrm{m}$.

crovessels (Gray, 1995; Dashwood and Thomas, 1997). Thus, $\mathrm{ET}_{\mathrm{A}} \mathrm{R}$-mediated pain behaviors could be caused by ischemia and subsequent acidosis rather than by a direct action on primary afferent fibers. However, data from the present study suggest that peripherally released ET could directly stimulate primary afferent neurons expressing $\mathrm{ET}_{\mathrm{A}} \mathrm{R}$. Observations that direct application of ET-1, but not the vasoconstrictor epinephrine, to the sciatic nerve of rats induces morphine-reversible nocifensive behavior also indicate that this nocifensive behavior is caused by direct actions on peripheral nerve versus indirect ischemic action (Davar et al., 1998).

Peripheral $\mathrm{ET}_{\mathrm{B}} \mathrm{Rs}$ have also been implicated as mediators of nociception, although primarily in inflammatory pain states. Whereas $\mathrm{ET}_{\mathrm{B}} \mathrm{R}$ agonists alone typically do not induce nocifensive behaviors, they potentiate such behaviors when administered after intraplantar injection of formalin or intra-articular injection of either carrageenan or bacterial lipopolysaccharide (Piovezan et al., 1997; De-Melo et al., 1998a). Furthermore, nocifensive responses after intraperitoneal administration of the inflammatory agent phenylbenzoquinone are absent in $\mathrm{ET}_{\mathrm{B}} \mathrm{R}$-deficient mice (Griswold et al., 1999). These studies, in combination with the present observation that ESCs and DRG satellite cells but not sensory neurons express $\mathrm{ET}_{\mathrm{B}} \mathrm{R}$, suggest that peripheral glia may be active participants in nociceptive signaling in the peripheral nervous system.

\section{Endogenous ET-1 in pain transmission}

Reports that $\mathrm{ET}_{\mathrm{A}} \mathrm{R}$ antagonists alleviate pain associated with diabetic neuropathy in rats (Jarvis et al., 2000) and that $E_{B} R$ antagonists alleviate inflammatory pain induced by administration of bacterial lipopolysaccharide (De-Melo et al., 1998b) suggest that endogenous ETs may be important in generating and maintaining persistent pain states. Patients with sickle cell anemia that were experiencing painful vaso-occlusive crises had elevated plasma ET-1 levels that increased with the level of pain and decreased as the pain and the crises subsided (GraidoGonzalez et al., 1998). Elevated plasma ET-1 levels may induce pain because intra-arterial injection of ET-1 results in long-lasting tactile allodynia and thermal hyperalgesia that spread along the injected arm (Dahlof et al., 1990). Furthermore, ETs have a strong homology with the sarafotoxins, a family of peptides present in the venom of the Israeli burrowing asp Atractaspis engeaddensis (Kochva et al., 1982). The painful effects of its bite are thought to be mediated by both $\mathrm{ET}_{\mathrm{A}} \mathrm{R}$ and $\mathrm{ET}_{\mathrm{B}} \mathrm{R}$ because different sarafotoxin isoforms found in this venom are potent and selective agonists at both $\mathrm{ET}_{\mathrm{A}} \mathrm{R}$ and $\mathrm{ET}_{\mathrm{B}} \mathrm{R}$ (Kochva et al., 1993).

There are a wide variety of cells that could release ET in peripheral tissues. Vascular endothelial cells produce and release ET-1 under normal conditions and increase their synthesis and release of this peptide in response to stimuli such as thrombin, insulin, and hypoxia (Gray, 1995). Low levels of shear stress also release ET-1 from cultured endothelial cells (Milner et al., 1992; Kuchan and Frangos, 1993), suggesting that damage to vasculature can release ET-1, which could then act on primary afferent nociceptors and/or ESCs.

Macrophages also synthesize and release ET-1 during airway inflammation in rats (Finsnes et al., 1998), and treatment of human macrophages with lipopolysaccharide also increases ET-1 synthesis and release (Ehrenreich et al., 1990).

Sensory neurons may be important sources of ET-1, and ET-1 may act in an autocrine or paracrine manner to excite these neurons. ET-1 mRNA is found in sensory neurons that express SP and CGRP (Giaid et al., 1989), and application of ET-1 to cultured DRG neurons potentiates capsaicin-induced CGRP release (Dymshitz and Vasko, 1994). These findings, combined with 

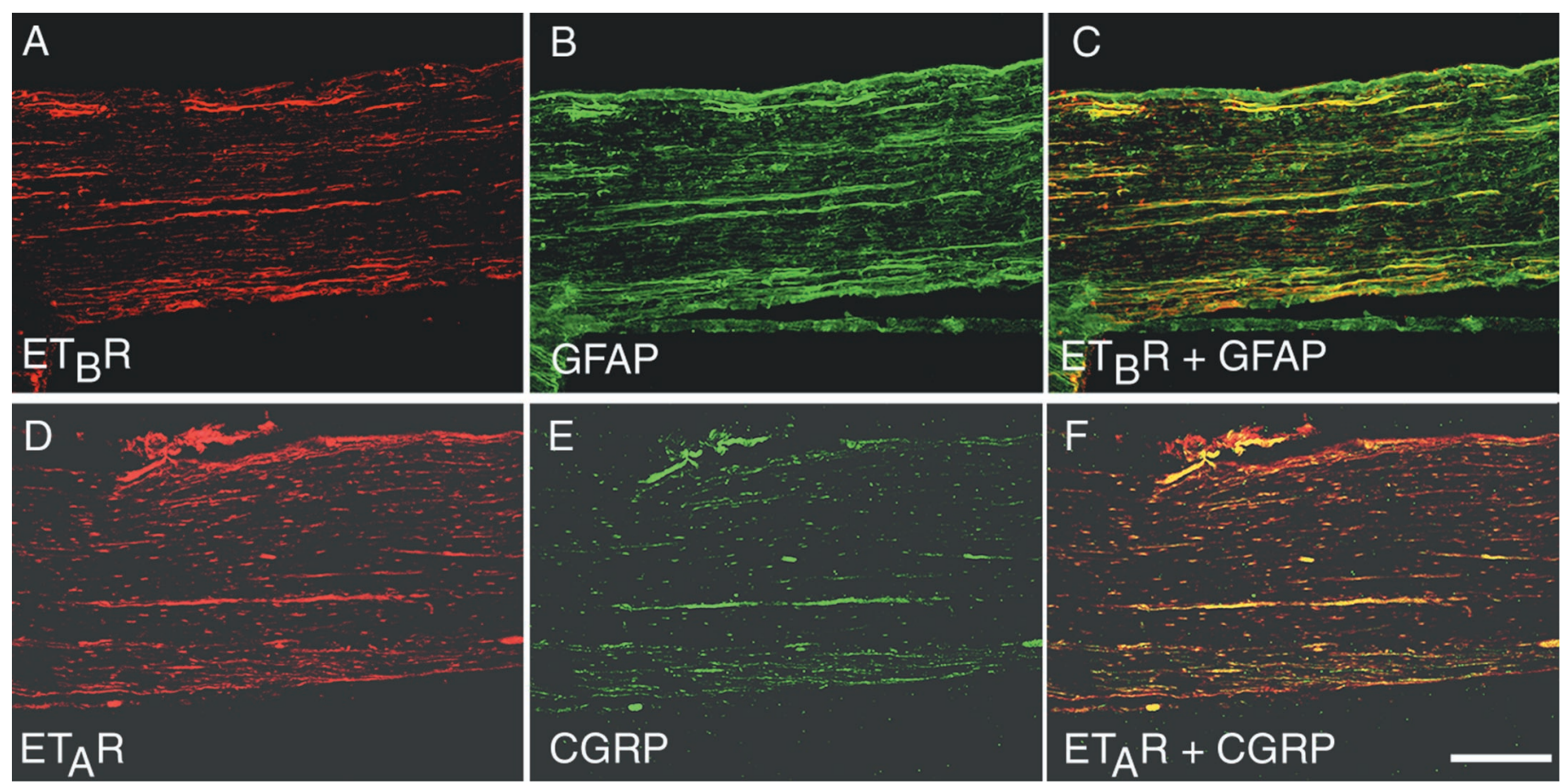

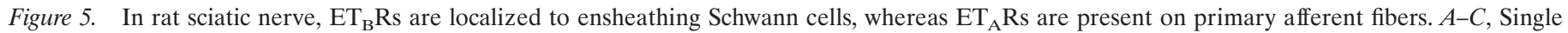
sections of rat sciatic nerve were double labeled for $\mathrm{ET}_{\mathrm{B}} \mathrm{R}(\mathrm{red} ; A)$ and GFAP ( green; $\left.B\right)$ and visualized with confocal microscopy to determine colocalization as indicated by yellow in $C . D-F$, Conversely, sections that were double labeled for $\mathrm{ET}_{\mathrm{A}} \mathrm{R}($ red; $D)$ and CGRP, a marker of primary afferent fibers ( green; E), showed colocalization as demonstrated by yellow in $F$. Scale bar, $200 \mu \mathrm{m}$.

the observations that CGRP-expressing sensory neurons also frequently express $\mathrm{ET}_{\mathrm{A}} \mathrm{R}$, are consistent with a role for $\mathrm{ET}_{\mathrm{A}} \mathrm{R}$ in sensory neurons as an autoreceptor. This may be especially important in neurogenic inflammation, a process dependent on the release of neuropeptides such as SP from primary afferent fibers (Lembeck and Holzer, 1979; Bozic et al., 1996). Plasma extravasation in the dura mater induced by electrical stimulation of the trigeminal ganglion is prevented by local administration of the mixed $\mathrm{ET}_{\mathrm{A}} \mathrm{R}$ and $\mathrm{ET}_{\mathrm{B}} \mathrm{R}$ antagonist bosentan (Brandli et al., 1996).

Endogenous ETs may also generate and maintain cancer pain because several different types of tumor cells synthesize and release ET-1 (Nelson et al., 1995; Kurbel et al., 1999). Thus, men with prostate cancer have significantly elevated plasma ET-1 levels (Nelson et al., 1995), and administration of an $E_{A} R$ antagonist reduces this cancer pain (Carducci et al., 1998). A recently developed murine model of bone cancer pain (Schwei et al., 1999) has allowed for testing of novel therapeutic agents (Honore et al., 2000b) and may thus provide further insight into the role of ET-1 in cancer pain.

\section{Peripheral glia as transducers of nociceptive information}

The findings that ESCs and DRG satellite cells (but not neurons) express $\mathrm{ET}_{\mathrm{B}} \mathrm{R}$, combined with previous reports on the efficacy of $\mathrm{ET}_{\mathrm{B}} \mathrm{R}$ antagonists in reducing inflammatory pain, indicate that peripheral glia may be involved in signaling nociceptive events in peripheral tissues. Peripheral glial cells are divided into several subtypes including MSCs, ESCs, and DRG satellite cells. MSCs and ESCs arise from the same neural crest-derived precursor cells but are driven to either the myelinating (MSCs) or the nonmyelinating (ESCs) phenotype by contact with developing axons (Jessen and Mirsky, 1999). In the adult, ESCs can be distinguished from MSCs in that they do not express myelinrelated proteins, but they express GFAP, Ran-1, and A5E3 (Jessen et al., 1990). Whereas each MSC myelinates one $\mathrm{A} \beta$ or Ad fiber to increase conduction velocity, ESCs envelop (but do not myelinate) several or even dozens of thin primary afferent fibers (Bunge and Fernandez-Valle, 1995). This proximity between ESCs and C fibers provides a structural basis by which cellular events occurring in ESCs could modify the excitability of these nociceptors. This may occur in part by ESCs buffering extracellular $\mathrm{K}^{+}$in the axonal environment (Robert and Jirounek, 1994) and regulating lipid metabolism (Fullerton et al., 1998).

DRG satellite cells share many similarities with ESCs. DRG satellite cells are morphologically distinct cells found in sensory ganglia, where they envelop small, medium, and large neuronal cell bodies. They are thought to maintain homeostasis in the DRG and may also modulate neurotransmission within the ganglia by regulating extracellular glutamate levels because they express the glutamate/aspartate transporter GLAST (Berger and Hediger, 2000) and by modulating ion flow between neuronal cell bodies (Shinder and Devor, 1994). DRG satellite cells may also modulate DRG neurons after spinal nerve ligation because after nerve injury, sympathetic efferent fibers invade the DRG and form pericellular "baskets" around DRG neurons (Sato and Perl, 1991; Chung et al., 1996). This sympathetic sprouting is known to be dependent on nerve growth factor (NGF) (Ramer et al., 1998; Ramer and Bisby, 1999). A likely source of NGF in this condition is DRG satellite cells because peripheral nerve axotomy induces a significant increase in NGF mRNA in corresponding DRG satellite cells (Zhou et al., 1999). Similar increases in NGF and brain-derived neurotrophic factor mRNA also occur in Schwann cells and DRG satellite cells during inflammation in peripheral tissues (Cho et al., 1997), suggesting that by altering the expres- 
sion and release of trophic factors, ESCs and DRG satellite cells may modulate nociceptive signaling. However, because $\mathrm{ET}_{\mathrm{B}} \mathrm{R}$ deficient mice show a significantly reduced inflammatory response to topical application of arachidonic acid (Griswold et al., 1999), modulation of inflammatory processes by other cells that express $\mathrm{ET}_{\mathrm{B}} \mathrm{R}$ may also have direct effects on the development of painful conditions.

ESCs and DRG satellite cells may also be able to signal inflammatory pain-related events by inducing the synthesis and release of compounds with known roles in inflammatory pain in response to $\mathrm{ET}_{\mathrm{B}} \mathrm{R}$ stimulation. ET-3, presumably acting at $\mathrm{ET}_{\mathrm{B}} \mathrm{R}$, induces cyclooxygenase- 2 and prostaglandin $\mathrm{E}_{2}$ expression in cultured astrocytes (Koyama et al., 1999) and potentiates the expression of inducible nitric oxide synthase induced by bacterial lipopolysaccharide (Oda et al., 1997).

The transmission of nociceptive information from peripheral tissues involves numerous neurotransmitters and neuromodulators to convey multiple types of pain. Although each pain state is unique, they all share the characteristic that they are initiated and sustained by tissue damage or pathology. Endothelins represent a family of pronociceptive peptides that may be involved in generating and maintaining pain in diabetic neuropathy, peripheral nerve injury, inflammation, and cancer. The presence of $\mathrm{ET}_{\mathrm{A}} \mathrm{R}$ on unmyelinated and thinly myelinated fibers and $\mathrm{ET}_{\mathrm{B}} \mathrm{R}$ on ESCs presents potential therapeutic targets for the development of novel analgesics, but perhaps more importantly, these results may enlarge our view of the role peripheral glia can play in nociceptive signaling in peripheral tissues.

\section{REFERENCES}

Aramori I, Nakanishi S (1992) Coupling of two endothelin receptor subtypes to differing signal transduction in transfected Chinese hamster ovary cells. J Biol Chem 267:12468-12474.

Baba A (1998) Role of endothelin B receptor signals in reactive astrocytes. Life Sci 62:1711-1715.

Basbaum AI (1999) Spinal mechanisms of acute and persistent pain. Reg Anesth Pain Med 24:59-67.

Berger UV, Hediger MA (2000) Distribution of the glutamate transporters GLAST and GLT-1 in rat circumventricular organs, meninges, and dorsal root ganglia. J Comp Neurol 421:385-399.

Bozic CR, Lu B, Hopken UE, Gerard C, Gerard NP (1996) Neurogenic amplification of immune complex inflammation. Science 273:1722-1725.

Brandli P, Loffler BM, Breu V, Osterwalder R, Maire JP, Clozel M (1996) Role of endothelin in mediating neurogenic plasma extravasation in rat dura mater. Pain 64:315-322.

Bremnes T, Paasche JD, Mehlum A, Sandberg C, Bremnes B, Attramadal $\mathrm{H}$ (2000) Regulation and intracellular trafficking pathways of the endothelin receptors. J Biol Chem 275:17596-17604.

Bunge R, Fernandez-Valle C (1995) Basic biology of the Schwann cell. In: Neuroglia (Kettenman H, Ransom B, eds), pp 44-57. New York: Oxford UP.

Carducci M, Bowling M, Rogers T, Leahy T, Janus T, Padley R, Nelson J (1998) Endothelin receptor antagonist, ABT-627, for prostate cancer: initial trial results. In: American Association for Cancer Research Meeting, C-24. Indian Wells, CA.

Cho HJ, Kim JK, Zhou XF, Rush RA (1997) Increased brain-derived neurotrophic factor immunoreactivity in rat dorsal root ganglia and spinal cord following peripheral inflammation. Brain Res 764:269-272.

Chung K, Lee B, Yoon Y, Chung J (1996) Sympathetic sprouting in the dorsal root ganglia of the injured peripheral nerve in a rat neuropathic pain model. J Comp Neurol 376:241-252.

Dahlof B, Gustafsson D, Hedner T, Jern S, Hansson L (1990) Regional haemodynamic effects of endothelin-1 in rat and man: unexpected adverse reaction. J Hypertens 8:811-817.

Dashwood M, Thomas P (1997) Neurovascular [125I]-ET-1 binding sites on human peripheral nerve. Endothelium 5:119-123.

Davar G, Hans G, Fareed MU, Sinnott C, Strichartz G (1998) Behavioral signs of acute pain produced by application of endothelin-1 to rat sciatic nerve. NeuroReport 9:2279-2283.

De-Melo JD, Tonussi CR, D’Orleans-Juste P, Rae GA (1998a) Articular nociception induced by endothelin-1, carrageenan and LPS in naive and previously inflamed knee-joints in the rat: inhibition by endothelin receptor antagonists. Pain 77:261-269.
De-Melo JD, Tonussi CR, D'Orleans-Juste P, Rae GA (1998b) Effects of endothelin-1 on inflammatory incapacitation of the rat knee joint. J Cardiovasc Pharmacol 31:S518-S520.

de Nucci G, Thomas R, D'Orleans-Juste P, Antunes E, Walder C, Warner TD, Vane JR (1988) Pressor effects of circulating endothelin are limited by its removal in the pulmonary circulation and by the release of prostacyclin and endothelium-derived relaxing factor. Proc Natl Acad Sci USA 85:9797-9800.

Dymshitz J, Vasko MR (1994) Endothelin-1 enhances capsaicin-induced peptide release and cGMP accumulation in cultures of rat sensory neurons. Neurosci Lett 167:128-132.

Ehrenreich H, Anderson RW, Fox CH, Rieckmann P, Hoffman GS, Travis WD, Coligan JE, Kehrl JH, Fauci AS (1990) Endothelins, peptides with potent vasoactive properties, are produced by human macrophages. J Exp Med 172:1741-1748.

Fareed M, Hans G, Atanda A, Strichartz G, Davar G (2000) Pharmacological characterization of acute pain behavior produced by application of endothelin-1 to rat sciatic nerve. J Pain 1:46-53.

Finsnes F, Christensen G, Lyberg T, Sejersted OM, Skjonsberg $\mathrm{OH}$ (1998) Increased synthesis and release of endothelin-1 during the initial phase of airway inflammation. Am J Respir Crit Care Med 158:1600-1606.

Fullerton SM, Strittmatter WJ, Matthew WD (1998) Peripheral sensory nerve defects in apolipoprotein E knockout mice. Exp Neurol 153:156-163.

Ghilardi JR, Allen CJ, Vigna SR, McVey DC, Mantyh PW (1994) Cholecystokinin and neuropeptide Y receptors on single rabbit vagal afferent ganglion neurons: site of prejunctional modulation of visceral sensory neurons. Brain Res 633:33-40.

Giaid A, Gibson SJ, Ibrahim BN, Legon S, Bloom SR, Yanagisawa M, Masaki T, Varndell IM, Polak JM (1989) Endothelin 1, an endothelium-derived peptide, is expressed in neurons of the human spinal cord and dorsal root ganglia. Proc Natl Acad Sci USA 86:7634-7638.

Graido-Gonzalez E, Doherty JC, Bergreen EW, Organ G, Telfer M, McMillen MA (1998) Plasma endothelin-1, cytokine, and prostaglandin E2 levels in sickle cell disease and acute vaso-occlusive sickle crisis. Blood 92:2551-2555.

Gray G (1995) Generation of endothelin. In: Molecular biology and pharmacology of the endothelins (Gray G, Webb DJ, eds), pp 13-37. Austin, TX: Landes.

Griswold DE, Douglas SA, Martin LD, Davis TG, Davis L, Ao Z, Luttmann MA, Pullen M, Nambi P, Hay DW, Ohlstein EH (1999) Endothelin B receptor modulates inflammatory pain and cutaneous inflammation. Mol Pharmacol 56:807-812.

Harris PJ, Zhuo J, Mendelsohn FA, Skinner SL (1991) Haemodynamic and renal tubular effects of low doses of endothelin in anaesthetized rats. J Physiol (Lond) 433:25-39.

Hokfelt T, Z hang X, Wiesenfeld-Hallin Z (1994) Messenger plasticity in primary sensory neurons following axotomy and its functional implications. Trends Neurosci 17:22-30.

Honore P, Rogers S, Schwei M, Salak-Johnson J, Luger N, Sabino M, Clohisy D, Mantyh P (2000a) Murine models of inflammatory, neuropathic, and cancer pain each generates a unique set of neurochemical changes in the spinal cord and sensory neurons. Neuroscience 98:585-598.

Honore P, Luger NM, Sabino MA, Schwei MJ, Rogers SD, Mach DB, O'Keefe P F, Ramnaraine ML, Clohisy DR, Mantyh PW (2000b) Osteoprotegerin blocks bone cancer-induced skeletal destruction, skeletal pain and pain-related neurochemical reorganization of the spinal cord. Nat Med 6:521-528.

Hori S, Komatsu Y, Shigemoto R, Mizuno N, Nakanishi S (1992) Distinct tissue distribution and cellular localization of two messenger ribonucleic acids encoding different subtypes of rat endothelin receptors. Endocrinology 130:1885-1895.

Jarvis MF, Wessale JL, Zhu CZ, Lynch JJ, Dayton BD, Calzadilla SV, Padley RJ, Opgenorth TJ, Kowaluk EA (2000) ABT-627, an endothelin ETA receptor-selective antagonist, attenuates tactile allodynia in a diabetic rat model of neuropathic pain. Eur J Pharmacol 388:29-35.

Jessen KR, Mirsky R (1984) Nonmyelin-forming Schwann cells coexpress surface proteins and intermediate filaments not found in myelinforming cells: a study of Ran-2, A5E3 antigen and glial fibrillary acidic protein. J Neurocytol 13:923-934.

Jessen KR, Mirsky R (1985) Glial fibrillary acidic polypeptides in peripheral glia. Molecular weight, heterogeneity and distribution. J Neuroimmunol 8:377-393.

Jessen KR, Mirsky R (1999) Developmental regulation in the Schwann cell lineage. Adv Exp Med Biol 468:3-12.

Jessen KR, Thorpe R, Mirsky R (1984) Molecular identity, distribution and heterogeneity of glial fibrillary acidic protein: an immunoblotting and immunohistochemical study of Schwann cells, satellite cells, enteric glia and astrocytes. J Neurocytol 13:187-200.

Jessen KR, Morgan L, Stewart HJ, Mirsky R (1990) Three markers of adult non-myelin-forming Schwann cells, 217c(Ran-1), A5E3 and 
GFAP: development and regulation by neuron-Schwann cell interactions. Development 109:91-103.

Kar S, Chabot JG, Quirion R (1991) Quantitative autoradiographic localisation of [125I]endothelin-1 binding sites in spinal cord and dorsal root ganglia of the rat. Neurosci Lett 133:117-120.

Kasuya Y, Abe Y, Hama H, Sakurai T, Asada S, Masaki T, Goto K (1994) Endothelin-1 activates mitogen-activated protein kinases through two independent signalling pathways in rat astrocytes. Biochem Biophys Res Commun 204:1325-1333.

Kitamura K, Shiraishi N, Singer WD, Handlogten ME, Tomita K, Miller RT (1999) Endothelin-B receptors activate Galpha13. Am J Physiol 276:C930-C937.

Kochva E, Viljoen C, Botes D (1982) A new type of toxin in the venom of snakes of the genus Atractaspis (Atractaspidinae). Toxicon 20:518-592.

Kochva E, Bdolah A, Wollberg Z (1993) Sarafotoxins and endothelins: evolution, structure and function. Toxicon 31:541-568.

Koyama Y, Mizobata T, Yamamoto N, Hashimoto H, Matsuda T, Baba A (1999) Endothelins stimulate expression of cyclooxygenase 2 in rat cultured astrocytes. J Neurochem 73:1004-1011.

Kuchan MJ, Frangos JA (1993) Shear stress regulates endothelin-1 release via protein kinase $\mathrm{C}$ and cGMP in cultured endothelial cells. Am J Physiol 264:H150-H156.

Kumara-Siri MH, Gould RM (1980) Enzymes of phospholipid synthesis: axonal versus Schwann cell distribution. Brain Res 186:315-330.

Kurbel S, Kurbel B, Kovacic D, Sulava D, Krajina Z, Dmitrovic B, Sokcevic M (1999) Endothelin-secreting tumors and the idea of the pseudoectopic hormone secretion in tumors. Med Hypotheses 52:329-333.

Lembeck F, Holzer P (1979) Substance P as neurogenic mediator of antidromic vasodilation and neurogenic plasma extravasation. Naunyn Schmiedebergs Arch Pharmacol 310:175-183.

MacCumber MW, Ross CA, Snyder SH (1990) Endothelin in brain: receptors, mitogenesis, and biosynthesis in glial cells. Proc Natl Acad Sci USA 87:2359-2363.

Mantyh PW, Gates T, Mantyh CR, Maggio JE (1989) Autoradiographic localization and characterization of tachykinin receptor binding sites in the rat brain and peripheral tissues. J Neurosci 9:258-279.

Mantyh PW, Rogers SD, Allen CJ, Catton MD, Ghilardi JR, Levin LA, Maggio JE, Vigna SR (1995) $\beta 2$-Adrenergic receptors are expressed by glia in vivo in the normal and injured CNS in the rat, rabbit, and human. J Neurosci 15:152-164.

Milner P, Bodin P, Loesch A, Burnstock G (1992) Increased shear stress leads to differential release of endothelin and ATP from isolated endothelial cells from 4- and 12-month-old male rabbit aorta. J Vasc Res 29:420-425.

Nelson JB, Hedican SP, George DJ, Reddi AH, Piantadosi S, Eisenberger MA, Simons JW (1995) Identification of endothelin-1 in the pathophysiology of metastatic adenocarcinoma of the prostate. Nat Med 1:944-949.

Oda H, Murayama T, Sasaki Y, Okada T, Nomura Y (1997) Endothelin enhances lipopolysaccharide-induced expression of inducible nitric oxide synthase in rat glial cells. Eur J Pharmacol 339:253-260.
Piovezan AP, D’Orleans-Juste P, Tonussi CR, Rae GA (1997) Endothelins potentiate formalin-induced nociception and paw edema in mice. Can J Physiol Pharmacol 75:596-600.

Piovezan AP, D’Orleans-Juste P, Souza GE, Rae GA, Tonussi CR (2000) Endothelin-1-induced ET(A) receptor-mediated nociception, hyperalgesia and oedema in the mouse hind-paw: modulation by simultaneous ET(B) receptor activation. Effects of endothelin-1 on capsaicin-induced nociception in mice. Endothelins potentiate formalin-induced nociception paw edema in mice. Br J Pharmacol 129:961-968.

Raffa RB, Schupsky JJ, Martinez RP, Jacoby HI (1991) Endothelin-1induced nociception. Life Sci 49:L61-L65.

Raffa RB, Schupsky JJ, Jacoby HI (1996a) Endothelin-induced nociception in mice: mediation by ETA and ETB receptors. J Pharmacol Exp Ther 276:647-651.

Raffa RB, Schupsky JJ, Lee DK, Jacoby HI (1996b) Characterization of endothelin-induced nociception in mice: evidence for a mechanistically distinct analgesic model. J Pharmacol Exp Ther 278:1-7.

Ramer MS, Bisby MA (1999) Adrenergic innervation of rat sensory ganglia following proximal or distal painful sciatic neuropathy: distinct mechanisms revealed by anti-NGF treatment. Eur $\mathrm{J}$ Neurosci 11:837-846.

Ramer MS, Kawaja MD, Henderson JT, Roder JC, Bisby MA (1998) Glial overexpression of NGF enhances neuropathic pain and adrenergic sprouting into DRG following chronic sciatic constriction in mice. Neurosci Lett 251:53-56.

Robert A, Jirounek P (1994) Uptake of potassium by nonmyelinating Schwann cells induced by axonal activity. J Neurophysiol 72:2570-2579.

Rogers SD, Demaster E, Catton M, Ghilardi JR, Levin LA, Maggio JE, Mantyh PW (1997) Expression of endothelin-B receptors by glia in vivo is increased after CNS injury in rats, rabbits, and humans. Exp Neurol 145:180-195.

Sato J, Perl E (1991) Adrenergic excitation of cutaneous pain receptors induced by peripheral nerve injury. Science 251:1608-1610.

Schwei MJ, Honore P, Rogers SD, Salak-Johnson JL, Finke MP, Ramnaraine ML, Clohisy DR, Mantyh PW (1999) Neurochemical and cellular reorganization of the spinal cord in a murine model of bone cancer pain. J Neurosci 19:10886-10897.

Shinder V, Devor M (1994) Structural basis of neuron-to-neuron crossexcitation in dorsal root ganglia. J Neurocytol 23:515-531.

Yanagisawa M, Kurihara H, Kimura S, Tomobe Y, Kobayashi M, Mitsui Y, Yazaki Y, Goto K, Masaki T (1988) A novel potent vasoconstrictor peptide produced by vascular endothelial cells. Nature 332:411-415.

Yoshizawa T, Kimura S, Kanazawa I, Uchiyama Y, Yanagisawa M, Masaki T (1989) Endothelin localizes in the dorsal horn and acts on the spinal neurones: possible involvement of dihydropyridine-sensitive calcium channels and substance $P$ release. Neurosci Lett 102:179-184.

Zhou XF, Deng YS, Chie E, Xue Q, Zhong JH, McLachlan EM, Rush RA, Xian CJ (1999) Satellite-cell-derived nerve growth factor and neurotrophin-3 are involved in noradrenergic sprouting in the dorsal root ganglia following peripheral nerve injury in the rat. Eur J Neurosci 11:1711-1722. 